УДК (477)94(470) "1850"

СКРИПНИК А. Ю.

https://orcid.org/0000-0002-3812-918X

https://doi.org/10.33577/2313-5603.33.2020.194-211

\title{
КАДРОВА РЕОРГАНІЗАЦІЯ РОСІЙСЬКИХ ЗБРОЙНИХ СИЛ НАПРИКІНЦ 50-х - НА ПОЧАТКУ 60-Х РОКІВ ХІХ СТОЛІТТЯ
}

У статті розглянуто трансформаційні процеси, які відбувалися в російській імператорській армії з середини 50-х рр. після дипломатичної й військової поразки у Східній (Кримській) війні проти коаліції європейських держав. Висвітлено комплексні заходи уряду і Військового міністерства, спрямовані на скорочення кількості особового складу частин і з'єднань. Показано створення і формування необхідної законодавчої бази, що регламентувала статус військовослужбовця у відпусті за межами військової частини. Окрема увага приділена намаганням командування збройних сил Російської імперії змінити принципи комплектування регулярних частин, зокрема прагнення покращити якість особового складу офіцерського корпусу. Висвітлено практику працевлаштування колишніх солдатів і офіцерів у цивільному житті та намагання губернських і місцевих органів влади сприяти цим процесам шляхом залучення до роботи у дворянських та місцевих управлінських структурах. Відображено зміни у соціальній структурі та середовищі міст і сіл Правобережної України у зв'язку з реформування імперських збройних сил та вплив збільшення кількості колишніх військових на їх взаємостосунки з місцевим населенням.

Ключові слова: Російська імперія, російські збройні сили, реформування, законодавча база.

Постановка проблеми та ї̈ актуальність. Зміст військової організації, оптимальна кількість особового складу та ефективні принципи оперативного управління збройними силами країни завжди були запорукою їх результативності у царині силового використання: в одному випадку 3 метою оборони держави, чи навпаки - здійснення агресивної, наступальної, загарбницької політики щодо сусідів. Відомо, що утримання великої армії $є$ чималим навантаженням на державний бюджет, тому прагнення до оптимального співвідношення „кількість - фінансові витрати” були і є актуальними. Яскравим прикладом стала російська імператорська армія першої половини XIX ст. часів правління Миколи I, де число вояків та їх термін служби були пріоритетом

Скрипник Анатолій Юрійович, доктор історичних наук, доцент, завідувач кафедри інформаційної діяльності, документознавства і фундаментальних дисциплін Подільського спеціального навчально-реабілітаційного соціальноекономічного коледжу, м. Кам'янець-Подільський.

(C) Скрипник А. Ю., 2020 
військового будівництва, а соціальним базисом став кріпосницький лад. Упродовж Східної (Кримської війни) стало зрозуміло, що така армія неефективна, а кількість солдатів не $є$ вирішальною перевагою перед озброєнням і організацією європейців. В результаті якість союзників перемогла кількість росіян.

Mета $i$ завдання дослідження. Початок другої половини XIX ст. в історії Російської імперії пов'язаний з постаттю царя Олександра II та його реформами. Серед радянсько-російських істориків поширена хибна думка про те, що військова реформа (1874 р.) під керівництвом військового міністра Д. Мілютіна стала початком змін у збройних силах імперії. Насправді, заміна рекрутських наборів на загальну військову повинність була другим (завершальним) етапом перетворень в армії з моменту закінчення Східної (Кримської війни). Тому завданням дослідження $є$ висвітлення складних у військово-організаційному і болючих в соціальному плані процесів початку докорінних кадрових змін у особовому складі російської імператорської армії наприкінці 50-х рр. XIX ст. Успішне студіювання теми створює грунт для об'єктивної оцінки подальших реформ у напрямах комплектування бойових частин, інтендантського забезпечення (постачання), озброєння та оперативного керівництва.

Аналіз попередніх досліджень і публікацій. Проблематика реформування армії в контексті інших реформ 60-70-х рр. потрапила у поле зору науковців ще наприкінці XIX ст. Російський військовий письменник О. Астаф'єв розглядав армію як живий організм і намагався вивести формулу „ідеальної армії”, в якій однострої мали бути захисного кольору, а вага спорядження піхотинця значно меншою за існуючу. В своїй праці „Про сучасне військове мистецтво" він наполягав на реформуванні армії після поразки у Східній (Кримській) війні, однак ці зміни мали б, на його думку, відбуватися у загальному контексті державного реформування Російської імперії (Астафьев, 1861).

Генерал-майор та військовий міністр Тимчасового уряду, а потім комбриг Червоної Армії О.І. Верховський був автором низки видань з військової теорії та історії. Саме у праці „Нарис з історії військового мистецтва в Росії XVIII і XIX ст.” він вводить поняття „Початок занепаду дворянської армії впродовж 1825-1856 рр.” (Верховский, 1922). На його думку, задля подальшої еволюції російське військо потребувало негайного реформування за зразками західноєвропейських збройних сил. 
Відомий радянський дослідник історії Російської імперії П. Зайончковський розглядав збройні сили як один 3 головних державних інститутів. Його праця „Військові реформи в Росії” мала на меті висвітлити основні ознаки військових перетворень у 1860-1870 pp., а саме: комплектування армії, іiі організацію, переозброєння, бойову підготовку військ після ганебної поразки у Східній війні (Зайончковский, 1952). У роботі встановлено хронологічні межі цих змін - 315 січня 1862 р. почав діяти план реорганізації, представлений Військовим міністерством, i до 1 січня 1874 р. - впровадження загальної військової повинності.

У 1992 р. вийшла книга Б. Меннінга „Багнети кращі за кулі: Імператорське російське військо, 1861-1914 pp". (Menning, 1992), у якій автор вдався до розгляду вад управління армією. Головною серед них американський дослідник вважає „парадоманію”, яка остаточно сформувалася в першій половині XIX ст. і стала анахронізмом, досягнувши свого розквіту за царювання Миколи I i Олександра II. Це тільки сприяло збереженню старих методів і поглядів на ведення війни до кінця XIX, що трансформувалося у відсутність взаємодії великих військових з'єднань, протидію поширенню у військах нових озброєнь та спорядження, реформування військової освіти.

Сучасна українська історіографія представлена працями дослідників Інституту історії України НАН України. Військово-політичні події Кримської війни та їх наслідки для України відображено у працях В. Волковинського і О. Реєнта (Волковинський, 2003; Реєнт, 2006; Реєнт, 2015).

В. Молчанов досліджував вплив військових реформ Д. Мілютіна на життєзабезпечення російських військових в українських губерніях в другій половині ХІХ ст. (Молчанов, 2012: 171-201). Автор проаналізував перехід від рекрутських наборів до системи загального призову на військову службу, зайнятість військових, грошове забезпечення офіцерів і нижчих чинів, харчування та забезпечення одностроями, умови проживання, користування транспортними послугами, санітарний стан, медичне забезпечення та дозвілля.

Виклад основного матеріалу. Після смерті Миколи I та поразки у Кримській війні започатковуються кардинальні перетворення у збройних силах імперії. Як влучно і оптимістично висловився один із сучасників: „Перестав гриміти барабан, а заговорив розум, i розпочалася енергійна робота з ліквідації негараздів у армії, які 
накопичилися протягом п'ятдесятирічного періоду постійних війн з 1805 по 1855 роки включно. Тривалий мілітарний відрізок гальмував інтелектуальний та економічний прогрес країни, вимагаючи від неї чималих зусиль” (Неизвестный, 1895: 134).

Реформування армії стало одним 3 найперших державницьких зрушень нового царя Олександра II. Сдиним виходом з існуючої кризової ситуації було суттєве зменшення чисельності збройних сил, спроба одночасного підвищення рівня їх боєздатності та скорочення фінансування. Імперським маніфестом 1856 р. цар скасував на три роки рекрутські набори, одночасно скоротивши термін дійсної служби з 19 до 15 років, 69000 осіб було звільнено від виконання військового обов'язку, а 421000 солдатів, офіцерів і генералів отримали безтермінові відпустки. Завдяки проведеним заходам загальна чисельність імперських збройних сил зменшилася 32300000 до 1300000 осіб. Відставні солдати і унтер-офіцери після звільнення змушені були самі собі шукати прихисток і заробіток у цивільному житті. Існувала можливість влаштуватися на службу в поліцію, прикордонну варту чи лісову сторожу за місцем проживання, 3 умовою хорошої атестації та вдалого проходження кадрового відбору (ПСЗРИ 3. № 31377).

„Головним завданням Військового міністерства стало зменшення військових витрат. Міністерство старанно взялося до справи. Не обмежуючись скороченням наявної кількості військ 3 одночасним переведенням їх на мирне становище, воно вдалося до скасування цілих частин, перегляду всіх штатів військ i військових управлінь 3 метою скорочення нестройового складу. Ця копітка робота Інспекторського департаменту тривала багато років; поступово скасовувалися різні команди: інвалідні, військоворобітничі, майстрові тощо. Результати не забарилися: бюджет Військового міністерства був доведений у 1859-1860 pp. до цифри близько 106 мільйонів рублів; число ж військ за штатами мирного часу передбачалося у 1860 р. - 798194 нижніх чинів” (Милютин, 1919: 246).

Одним із швидких і дієвих шляхів стало скорочення особового складу через систему відпусків, яку створив ще батько Олександра II у 30-40 pp. XIX ст. Загалом вона довела свою ефективність, але потребувала корегування відповідно до нових реалій та підвищення універсальності (Копия Циркуляра Министерства внутренних дел об устройстве уволенных из армии 
нижних чинов и черновик докладной записки Голищьлна М. Ф. Московскому губернатору сентябрь 1852 г., л. 2-7). Першими кроками стала низка наказів, обнародуваних у квітні 1856 р.: про припинення прийому на службу вдруге відставних солдат 3 особливими перевагами і пільгами, що скорочувало зайві фінансові витрати; про порядок звільнення офіцерів у відпустки за сімейними обставинами; насправді це була тільки офіційна причина, звільнялися майже усі бажаючі, в тому числі й штабні офіцери, як-от полкові й батальйонні ад’ютанти та жалонерні офіцери (вони окреслювали лінію фронту при шикуванні полку - А. С.), іноді за станом здоров'я; так само солдат і унтер-офіцерів відправляли у відставку та безтермінові відпустки ,[...] для полегшення військам [...]” (ПСЗРИ 1. № 30379; № 30409; № 30410; № 30454; № 31161).

Першочергово звільнялися поранені і покалічені вояки. Міністр внутрішніх справ С. Ланской циркулярним приписом наказав начальникам губерній у листопаді 1857 р. терміново надати списки таких звільнених у відставку нижніх чинів, які мали паспорти та інші документи, на призначення пенсій та усіх належних за законами пільг (Циркуляри Київського військового, Подільського і Волинського генерал-губернатора за 1858-1860 рр. Січень 1858 р., арк. 3). Водночас, зважаючи на велику кількість поранених, що перебували у військових та цивільних шпиталях, на початку 1856 р. вийшов маніфест Олександра II із запрошенням цивільних лікарів на військово-медичну службу. Обіцяли 100 рублів на рік жалування, житло, однострої та харчування (Маніфест цүаря Олександра II, укази Сенату по залученню приватних лікарів на військову службу, грудень 1856 р., арк. 6-7).

15 травня 1856 р. вийшли „Правила звільнення з війська нижніх чинів у відпустки і відставку”, за якими з метою скорочення i переформування збройних сил відповідно до мирного часу планувалося звільнити надлишкову кількість військовослужбовців. Як і раніше, за зразкову службу надавалися безтермінові відпустки тим, хто прослужив у армії 20 років, у гвардії 15 років відповідно (Относительно нижних чинов, которые считаются поступившими в госпитали и больницы: в войну 1853-1856 годов. Январь 1864 2., C. 1). Крім того, допускалося звільнення у тимчасові відпустки із зарахуванням до резервних військ старанних i 
зразкових солдатів, які не прослужили визначених термінів, однак були гідні нетривалого звільнення додому (§ 1). Нововведенням став розподіл відпускників на два розряди: комплектних і надкомплектних. До першого розряду віднесли нижніх чинів старших термінів служби, яких приписали до діючих і запасних частин за штатами військового часу. До другого зарахували відпускників менших термінів служби, які залишалися в губерніях у більшій, ніж потрібно кількості для поповнення діючих і формування нових частин у мирний час. Їх планували поступово повертати до військ на поповнення браку особового складу у частинах $(\S 2 ; 3 ; 4)$. У „Правилах” детально регламентувався порядок звільнення, оформлення належних документів, забезпечення грошима, амуніцією і харчами, питання транспортування, порядок бюрократичного листування між військовими установами, порядок обліку прибулих на місця відпускних губернськими установами (ПСЗРИ 2. № 30493; № 30906; № 30906).

Учасник цих подій пригадував: „Уряд швидко переводив армію на мирний стан. Роззброєння і переформування розпочалося ще у першій половині 1856 р. і тривало до кінця 1858 р. Оскільки наші головні сили були зосередженні на Півдні, то саме звідси в усі куточки Росії потягнулися партії відставних і безтермінововідпускних нижніх чинів. Звільняли переважно старих служивих, багато з них вже давно вислужили свої терміни, але через війну змушені тягнути лямку. Більшість ветеранів пошкандибали до своїх губерній, щоб заспокоїти свої старі кістки на батьківщині” (Неизвестныци, 1895: 121).

Представників дворянства влада також намагалася якимось чином влаштувати. Одним 3 варіантів, на який дав згоду монарх у січні 1857 р., був дозвіл генералам, зарахованим до запасних військ, та штаб і обер-офіцерам, звільненим у безтермінові відпустки, на право займати посади за вибором дворянства, а термін цієї служби зараховувати як тотожний до військового. Більше того, дозволялося підвищення в чинах майорів і обер-офіцерів у своїх полках, якщо приходив термін і вислуга років, незважаючи на те, що вони перебували на цивільних посадах (ПСЗРИ 9. № 34401). Через рік, у лютому 1858 р., вийшли „Правила”, які регламентували порядок тимчасового звільнення офіцерів-дворян, що мали маєтки в певній губернії. За умови, „[...] якщо вони бажають взяти участь у зборах дворян з метою обговорення пропозицій 
щодо покращення та облаштування побуту поміщицьких селян, так і у виборах членів Комітету, що впроваджуються з цією метою по губерніях, - мають право просити про звільнення на два місяці в ті губернії, де знаходяться їх маєтки” (ПСЗРИ 7. № 32740). Інша частина офіцерів взагалі наважувалася змінити військову службу на цивільну. Тим більше, що саме законодавство імперії заохочувало до цього старших офіцерів. У червні 1859 р. вийшов закон, який регламентував не тільки перехід до „статської служби”, а й зберігав і підвищував у чинах бажаючих це зробити. Так офіцери армії й гвардії, починаючи зі штабс-капітана і вище, за умови перебування у своєму чині більше трьох років на військовій службі, в разі переходу до цивільного відомства отримували наступний чин відповідно до „Табелів про ранги”, якщо менший отримували аналогічний, тільки цивільний. Наприклад, штабскапітан одразу ж набував чину колезького асесора VIII класу, а полковник - статського радника V класу і так далі (Скрипник, 2015(a): 41).

Потрібно зауважити, що скорочення армії Олександром II не було масовим і одночасним. Все залежало від стану полків і з'єднань, їх розташування та ситуативного бачення процесу самими командирами (Журнал Департамента Государственной Экономии по делу об устройстве отставных и бессрочноотпускных солдат, с приложением замечаний Ворониова М. С. по делам командуемого ним 2-го пехотного корпуса март 1956 г., л. 13). Тому вийшла „Відомість про діючі, резервні і запасні частини гвардії, гренадерського і армійських корпусів, з порядком: коли належить здійснити звільнення нижніх чинів у відставку і відпустки”. Кожній $з$ дивізій усіх корпусів було зазначено, коли і де провести звільнення своїх солдатів. Відповідно, це скорочення впливало на забезпечення бойових частин усім необхідним. Цивільне губернське керівництво поставили до відома про дозвіл „[...] всебічного скорочення витрат на армію. За наказом командувача дозволялося припинення іррегулярним (козацьким полкам кавалерії- А. С.) i частково регулярним частинам додаткового приварочного довольства розташованих на широких квартирах, 3 продовженням приварку від обивателів по усій території губернії”. Тобто, держава, заощаджуючи на військових витратах, переклала тягар іiї утримання на плечі місцевого населення (Циркуляри Подільського губернського правління і листування з ним про відведення пасовиськ для коней військових частин, грудень 1867 р., арк. 41). 
Ускладнення і зміни самого механізму відпускної системи спричинило певне збільшення і вдосконалення порядку контролю та обліку військовослужбовців. Насамперед, це торкнулося основного документа, яким забезпечувалися військовослужбовці, а саме - відпускних білетів. 3 квітня 1857 р. були введені нові зразки: звільненим у тимчасову відпустку понадкомплектним, що вислужили 15 років, видавали білети на жовтому папері; у безтермінову відпустку, той самий термін - на червоному; ветеранам, які вислужили 20 років і відставним солдатам, - на папері білого кольору. За миколаївських часів білети таких кольорів використовувалися для спрощення контролю за військовими міською і земською поліціями, а особливо сільським начальством, серед якого було багато неграмотних. Тобто, білет білого кольору мали відставні солдати, а власник білету червоного кольору мав проходити щорічні військові збори, і представникам влади варто було тільки подивитися на колір білета, не читаючи його. 3 моменту скасування цих зборів Олександром II зазнали відповідних змін і документи, їх оптимізували до тогочасних вимог i потреб. Відпускних вояків також легко було відрізнити за спеціальними нашивками на погонах чорного чи червоного кольорів на одностроях: якщо солдат перебував у безтерміновій відпустці, то мав по дві нашивки на погоні, якщо у тимчасовій - тільки одну (ПСЗРИ 5. № 31762; № 32461; Чертежи и рисунки. к № 32461).

Відпускна кампанія 1856-1858 рр. виявилася найбільшою за весь час існування російського регулярного війська. „Можна сказати, що з цим звільненням розійшлася по домівках майже вся стара миколаївська армія - розійшлася, щоб більше ніколи не повернутися до іiі лав. Тому що контингент молодих солдатів, які вступили на службу перед початком та під час Східної війни, був досить великим" (Неизвестный, 1895: 122).

Істотне скорочення збройних сил імперії, а відповідно поява у містах і селах великої кількості відпускних солдатів додала роботи місцевим поліціям, слідчим та судовим органам. Спектр злочинів і порушень був досить широкий. Доходило до банальних речей - крадіжок харчів. Уланівське станове правління та становий пристав 5-го стану звернулися до Літинського повітового суду Подільської губернії зі справою про відпускного каноніра Шандрюка Єфима, який у нетверезому стані вкрав 3 хліва дячка села Митонечне Ананія Стрельбицького харчі на 
суму 50 копійок, „[...] бо хотів дуже їсти”. Дячок пробачив солдату цю провину, а суд зробив йому офіційне попередження „Якщо щось подібне ще станеться, то відправлять назад у полк” (Справа за обвинуваченням безтерміново-відпускного каноніра Шандрюка Юхима в крадіжках харчових припасів дячка Стрельбіиького, червень 1872 р., арк. 1-2; 26-27). Іноді відпускні солдати, повертаючись зі служби, не мали куди поселитися, їх майно i нерухомість були продані. Відпускний бомбардир Євстратій Семенов скаржився Миколі I, що після 17-річної служби повернувся в місто Звенигородку і застав батьківське майно (будинок 3 прибудовами, город та угіддя) проданими сестрою тутешньому міщанину I. Федченку. Просив царя згідно із законами повернути йому власність через міську поліцію. Власник теж написав скаргу царю про те, що солдат знав про продаж будинку, а зараз вимагає його повернути. Судова тяганина у повітовому суді за участю чиновників міського магістрату ні до чого не призвела. Тільки Київська палата цивільного суду наказала міщанину сплатити солдату половину вартості майна - 40 рублів сріблом (Справа про привласнення міщанином Ткаченком спадкового будинку, що належить відставному бомбардиру Сліпченку, травень 1855 р., арк. 1; 8-9; 28-32; 58). Траплялися випадки участі солдатвідпускників у локальних соціальних конфліктах. Рядовий Клим Березов разом із земляками-селянами в Ольгопільському повіті Подільської губернії напав на будинок місцевого лихваря Франца Краєвського, завдавши тому тілесних ушкоджень. Слідство виявило, що майже усі мешканці села перебували у фінансовій кабалі в лихваря, який шляхом стягування великих відсотків розорював їхні господарства. Військова комісія не взяла до уваги заслуги Березова на службі, його зразкову дисципліну та медалі за участь у Кримській війні та придушенні польського повстання 18621863 pp., і відправила назад у полк. Селян-поплічників оштрафували на 7 рублів (За звинуваченням безтерміново-відпускного рядового Березова Клима і селян Полішука Феодосія, Шевчишина Порфірія у нападі на будинок Краєвського Франияа, листопад 1868 р., арк. 9-10; 93-95).

Якщо солдатів і унтер-офіцерів звільняли за гарну поведінку і старанність, то з ініціативи царя армія почала радикальними методами позбавлятися поганих офіцерів. На початку серпня 1856 р. 
вийшов наказ, за яким полкові командири отримували право подавати начальникам дивізій списки ,[...] штаб і обер-офіцерів, які не атестуються по формулярних і кондуїтних (у військовому відомстві так називалися особливі списки про поведінку і здібності офіцерів - А. С.) списках за нетверезу, погану і розпусну поведінку та низьку моральність, неспроможність виконувати свої службові обов'язки, підозріло часті рапорти про хвороби [...]". 3 їх дозволу і згоди полкові командири пропонували таким офіцерам подавати прохання про звільнення зі служби, а на випадок відмови - самостійно направляти рапорти на затвердження вищому керівництву. У разі факту відставки таких офіцерів у наказах по полках не оголошували причин звільнення і не приймали скарг про реабілітацію та рапортів скасування наказу через суд (Скрипник, 2015(b): 196). У вищі інстанції почали потоком надходити скарги, доноси, прохання саме від непридатних офіцерів, які за будь-що прагнули залишитися на службі. Одночасно у цій відпускній компанії з'явився й політичний складник. Жандарми через командирів полків і місцеві поліційні структури почали таємно складати списки потенційно неблагонадійних офіцерів польського походження. Насамперед це стосувалося відставних обер-офіцерів по кожному повіту Волинської і Подільської губерній. В іменних списках зазначалося від 5 до 20 осіб по кожному повіту (Циркулярні листи Волинського губернського правління про зберігання документів, діяльності польського революційного комітету і надання відомостей про офічерів-поляків мешканиів повітів. Рапорти станових приставів про персональні списки, серпень 1863 р., арк. 5-9).

„Почистивши” таким чином армію від небажаних офіцерів, 3'явилася можливість надати відпустки тим, хто продовжував служити „[...] у вигляді тимчасового заходу, дозволити штаб і обер-офіцерам, за їх бажанням, звільнятися у безтермінову відпустку, якщо вони прослужили три роки”. Сдиною умовою обмеження бажаючих було підтримання належної боєздатності у військах, що передбачало присутність певної кількості офіцерів у частинах (ПСЗРИ 4. № 31679). Втім, відпускний ажіотаж охопив усі збройні сили імперії, незважаючи на місця розташування. До Військового міністерства все частіше стали надходити представлення на офіцерів, які не підпадали під встановлені правила, але прагнули отримати відпустку. 
3 кінця 1857 р. звільнення у тимчасові відпустки проводилося відповідно до затверджених царем циркулярів Інспекторського департаменту Військового міністерства. У них зазначалося, скільки і коли можна звільнити по окремих армійських корпусах, а де зовсім заборонити, окреслювалися терміни і черговість частин. До прикладу, був призначений загальний термін: з початку 1858 р. до 1 квітня, чи з дозволу керівництва до 1 травня (ПСЗРИ 6. № 32517). У червні того ж року наступний циркуляр дозволяв звільняти за існуючими правилами після закінчення літніх навчань у військах, тобто з серпня-вересня на наступні шість місяців (ПСЗРИ 8. № 33294).

На початку цього ж року вийшло чергове „Височайше повеління" 3 правилами i регламентацією поведінки військовослужбовців у відпустці, яке було поширене серед місцевих губернських установ та у періодичній пресі (Bысочайшее повеление. 1858 г., C. 1). Воно нагадувало нормативні документи миколаївської доби: критерії звільнення 3 війська та терміни вислуги залишалися такими самими; вимоги до відпускників тлумачилися традиційно „[...] у відпустці поводити себе тверезо і пристойно, зберігати військовий вишкіл, бороду брити, по світу не ходити, одягатися достойно"; порушників негайно відправляти назад у полки; місцевій поліції наглядати і контролювати військових, а за дрібні провини забирати до буцегарні (Wirtschafter, 1995, p. 232).

У другій половині 50-х рр. спостерігається тенденція до збільшення кількості відпускників на території Київського генералгубернаторства. До загального числа 33262 військовослужбовців регулярних військ у Київській губернії, на 1859 р. мешкало 16194 безтерміново-відпускних, 8637 відставних солдатів зі своїми родинами у кількості 32783 особи та солдатських синів і кантоністів нараховувалося 11030 (Сборник статистических сведений, о Киевской губернии за 1859 год: 32). У Подільській губернії на той самий час перебувало 20945 солдатів і офіцерів армійських полків, 14834 безтерміново-відпускних, відставних солдатів обліковували у кількості 7674 і членів їх сімей ще 15944, солдатських дітей і кантоністів - 14237 (Памятная книжка Подольской губернии на 1859 год: 112). Зважаючи на скорочення кількості військового контингенту, який перебував у межах губерній під час 
Кримської кампанії, і одночасне збільшення числа відпускників та відставних солдатів, так званий „військовий прошарок” значно збільшився порівняно з минулими десятиріччями.

Висновки. Поразка у масштабному військовому конфлікті Російської імперії з європейськими країнами в середині XIX ст. стала відображенням недоліків у будівництві імперських збройних сил. Зокрема, Східна (Кримська) війна розкрила кілька основних причин хибної мілітарної стратегії, що десятиріччями базувалася на існуючому кріпосному праві. Усім стало очевидно, що армія, виплекана Миколою I, потребувала кардинальних змін. На такі зміни наважився Олександр II. Керуючись державницькими інтересами, розуміючи ситуативну практичну неефективність та фінансову обтяжливість для імперії він насмілився на радикальну руйнацію (модернізацію) армії, зразка XVIII - першої половини XIX ст. По-друге, скористався розробленою ще у 20-30-х рр. багаторівневою відпускною системою та наявними запасними $\mathrm{i}$ резервними військами, які дозволяли скоротити кількість регулярних частин, але водночас підтримувати армію у належній бойовій готовності. По-третє, кадрові зміни у збройних силах Російської імперії згодом вплинули на соціальну структуру суспільства 3 появою у містах і селах певного відсотка колишніх військовослужбовців. Очевидно, що кадрове реформування армії стало одним 3 важливих напрямів реформ у міліарній сфері та водночас віддзеркаленням глибоких соціально-економічних змін У російській державній машині другої половини XIX ст.

\section{Використані посилання}

Астафьев А. И. (1856-1861) О современном военном искусстве: Ч. 1-2. Санкт-Петербург: тип. Почтового департамента.

Верховский А. И. (1922) Очерк по истории военного искусства в России XVIII u XIX вв. Москва: Высший военный редакционный совет, 279 с.

Волковинський В. М. (2003) Військові реформи 60-70-х рp. ХІХ cm. В: Енциклопедія історії України: у 10 т. редкол.: В. А. Смолій (голова) та ін.; Інститут історії України НАН України. Київ: Наук. думка,. Т. 1 : А-В. 688 с.

Волковинський В. М., Реєнт О. П. (2006) Украӥна у Кримській війні 18531856 рp. (до 150-річчя Східної війни). Київ: Інститут історії України НАН України. $211 \mathrm{c.}$

Высочайшее повеление. Отдел второй. Часть 1-я Официальная. Подольские Губернские Ведомости. № 7.1858 г. С. 1. 
Журнал Департамента Государственной Экономии по делу об устройстве отставных и бессрочноотпускных солдат, с приложением замечаний Воронцзова М. С. по делам командуемого ним 2-го пехотного корпуса. Российский государственный архив древних актов (РГАДА). Ф. 1261, (Кн. Гр. Воронцовы). Оп. 1, Д. 2247, Л. 3-27.

За звинуваченням безтерміново-відпускного рядового Березова Клима $i$ селян Полішука Феодосія, Шевчишина Парфірія у нападі на будинок Краєвського Франияа. Держархів Хмельницької області. Ф. 642, (Комісія військового суду при управлінні Кам'янець-Подільського військового начальника). Оп. 1, Спр. 6, Арк. 9-10; 93-95.

Зайончковский П. А. (1952) Военные реформы 1860-1870 г2. в России. Москва: Издательство МГУ, 375 с.

Копия Циркуляра Министерства внутренних дел об устройстве уволенных из армии нижсих чинов и черновик докладной записки Голицына М. Ф. Московскому губернатору. РГАДА Ф. 1263 (Кн. Голицыны), Оп. 6, Д. 6, Л. 2-7.

Маніфест ияаря Олександра II, укази Сенату по залученню приватних лікарів на військову службу. Державний архів Хмельницької області. Ф. 69 (Подільська губернська лікарська управа), Оп. 1, Спр. 442, Арк. 6-7.

Милютин Д. А. (1919) Воспоминания. Том 1. (1816-1843). Москва: Изд. Военной Академии, 469 с.

Молчанов В. Б. (2012-2013) Вплив воєнних реформ Д. О. Мілютіна на життєзабезпечення російських військових в українських губерніях в другій половині XIX ст. Проблеми історії України ХIX-початку XX cm. Вип. ХХ. С. 171-201, Вип. XXII. С. 78-120.

Неизвестный (1895) Воспоминания за много лет. 1844-1884 гг. Русская старина. Год XXVI-й. Том LXXXIII. Вып. 2. Санкт-Петербург, С. 121-134.

Относительно нижних чинов, которые считаются поступившими в госпитали и больницы: в войну 1853-1856 годов. Высочайшие повеления. Часть официальная. Подольские Епархиальные Ведомости. 15 января 1864 года. № 2. С. 1.

Памятная книжка Подольской губернии на 1859 год. Изданная Редакцией Подольских губернских ведомостей (1859). Каменец-Подольск. 177 с.

ПСЗРИ 1. Закон № 30379. О прекращении приема на вторичную воинскую службу отставных нижних воинских чинов с особыми за сие преимуществами; Закон № 30409. О порядке увольнения офицеров в отпуски по домашним обстоятельствам, в 1856 году; Закон № 30410. О порядке отправления на родину нижних чинов, подлежащих увольнению в отставку; Закон № 30454. О порядке увольнения в отпуск офицеров с сохранением содержания; Закон № 31161 . О порядке увольнения в бессрочный отпуск штаб и обер-офицеров. В: Полный свод законов Российской империи (далі- ПСЗРИ-ІІ). Т. XXXI. Отд. 1. СанктПетербург: Тип. ІІ Отд. Собств. Е.И.В. канц., 1857.

ПСЗРИ 2. Закон № 30493. Высочайше утвержденные Правила для увольнения из войск нижних чинов в отпуски и в отставку; Закон № 30906. О форме билета для нижних чинов, поступивших, в минувшую войну, на службу в войска, охотою, из государственных крестьян, и подлежащих ныне увольнению в бессрочный отпуск; К закону № 30906. Форма билета для нижних чинов, поступивших на службу в военное время, по охоте, из государственных крестьян. В: ПСЗРИ-ІІ. Т. ХХХІ. Отд. 1.; Отд. 2. Санкт-Петербург: Тип. II Отд. Собств. Е.И.В. канц., 1857. 
ПСЗРИ 3. Закон № 31377. О преимуществах генералов в запасных войсках и бессрочно-отпускных офицеров, занимающих должности по выборам дворянства. В: ПСЗРИ-ІІ. Т. ХХХІІ. Отд. 1. Санкт-Петербург: Тип. ІІ Отд. Собств. Е.И.В. канц., 1858. С. 36.

ПСЗРИ 4. Закон № 31679. О порядке увольнения в бессрочный отпуск штаб и обер-офицеров. В: ПСЗРИ-ІІ. Т. ХХXII. Отд. 1. Санкт-Петербург: Тип. II Отд. Собств. Е.И.В. канц., 1858. С. 268-269.

ПСЗРИ 5. Закон № 31762. О цвете бумаги для билетов бессрочно-отпускных нижних чинов; Закон № 32461. О форме погонов и нашивок или гаек для нижних чинов находящихся в бессрочном или временном отпусках; Чертежи и рисунки к закону № 32461. Рисунок к плечевым погонам с нашивками из черного сукна для нижних чинов, находящихся в отпусках. В: ПСЗРИ-II. Т. XXXII. Отд. 1.; Отд. 2. Санкт-Петербург : Тип. ІІ Отд. Собств. Е.И.В. канц., 1858.

ПСЗРИ 6. Закон № 32517. О увольнении нижних чинов в кратковременные отпуски. В: ПСЗРИ-ІІ. Т. ХХХІІ. Отд. 1. Санкт-Петербург: Тип. ІІ Отд. Собств. Е.И.В. канц., 1858. С. 982-983.

ПСЗРИ 7. Закон № 32740. Высочайше утвержденные Правила об увольнении генералов, штаб и обер-офицеров, состоящих на службе в войсках и военных Управлениях, для участвования в собраниях дворян и разрешении им, в случае избрания в члены Губернских Комитетов, оставаться там во все время существования сих комитетов. В: ПСЗРИ-ІІ. Т. ХХХІІІ. Отд. 1. Санкт-Петербург: Тип. ІІ Отд. Собств. Е.И.В. канц., 1860. С. 91-92.

ПСЗРИ 8. Закон № 33294. О сроках для увольнения, в 1858 году, нижних чинов в бессрочный отпуск. В: ПСЗРИ-ІІ. Т. ХХХІІІ. Отд. 1. Санкт-Петербург: Тип. ІІ Отд. Собств. Е.И.В. канц., 1860. С. 753-754.

ПСЗРИ 9. Закон № 34401. О назначении в полицию людей из военного ведомства, вполне соответствующих полицейской службе. В: ПСЗРИ-ІІ. Т. ХХХІІІ. Отд. 1. Санкт-Петербург: Тип. ІІ Отд. Собств. Е.И.В. канц., 1861. С. 376.

Реєнт О. П. (2015) Чому Кримська війна 1853-1856 рр. стала явищем міжнародного суспільного життя? В: Історія Криму в запитаннях та відповідях. Київ: НАН України. Інститут історії України, 527 с.

Сборник статистический сведений о Киевской губернии за 1859 год (с адрескалендарем лии служащих в губернии на 1861 год) (1861) Киев: Типография Губернского Управления, 281 с.

Скрипник А. Ю. (2015) Порядок та особливості звільнення офіцерів збройних сил Російської імперії у 30-х-50-х рр. XIX ст. Вісник Кам'янецьПодільського національного університету імені Івана Огієнка. Історичні науки. Вип. 8. С. 192-200.

Скрипник А. Ю. (2015) Політика кадрової мілітаризації місцевого управлінського апарату губерній Правобережної України в 20-х - 60-х рр. XIX ст. Часопис украӥнської історії. Вип. 32. С. 38-45.

Справа за обвинуваченням безтерміново-відпускного каноніра Шандрюка Юхима в крадіжках харчових припасів дячка Стрельбічького. Держархів Вінницької області. Ф. Д-222, (Літинський повітовий суд), Оп. 1, Спр. 620, Арк. 1-2; 5-6 зв.; 26-27.

Справа про привласнення міщанином Ткаченком спадкового будинку, щзо належить відставному бомбардиру Сліпченку. Державний архів Черкаської області. Ф. 834, (Звенигородський городовий магістрат). Оп. 1, Спр. 290, Арк. 1-1зв.; 8-9; 28-32; 58. 
Циркуляри Київського військового, Подільського і Волинського генералгубернатора за 1858-1860 рр. Держархів Рівненської області. Ф. 567, (Міський магістрат, м. Дубно). Оп. 1, Спр. 3, Арк. 3.

Циркуляри Подільського губернського правління і листування з ним про відведення пасовиськ для коней військових частин. Державний архів Вінницької області. Ф. Д-200 (Вінницький повітовий предводитель дворянства), Оп. 1, Спр. 372, Арк. 41.

Циркулярні листи Волинського губернського правління про зберігання документів, діяльності польського революиійного комітету і надання відомостей про офічерів-поляків мешканців повітів. Рапорти станових приставів про персональні списки. Державний архів Рівненської області. Ф. 379 (Рівненський повітовий справник). Оп. 2, Спр. 2, Арк. 5-9.

Menning B. W. (1992) Bayonets before Bullets. The imperial Russian Army, 1861-1914. Bloomington and Indianapolis, $335 \mathrm{p}$.

Wirtschafter E. K. (1995) Social Misfits: Veterans and Soldiers' Families in Servile Russia. The Journal of Military History, Vol. 59, No. 2, pp. 215-235.

\section{References}

Menning B. W. (1992) Bayonets before Bullets. The imperial Russian Army, 1861-1914. Bloomington and Indianapolis, $335 \mathrm{p}$.

Wirtschafter E. K. (1995) Social Misfits: Veterans and Soldiers' Families in Servile Russia. The Journal of Military History, Vol. 59, No. 2, pp. 215-235.

Astafiev A. I. (1856-1861) On contemporary military art: Part 1-2. SaintPetersburg: Typography of Post department.

Verkhovskii A. I. (1922) Outline of military history in Russia of the $18^{\text {th }}$ and $19^{\text {th }}$ cent. Moscow: Higher military editorial council. $279 \mathrm{p}$.

Volkovynskyi V. M. (2003) Military reforms of 60-70-ies of the $19^{\text {th }}$ cent. in: Encyclopedia if history of Ukraine : in 10 vol. Edit.: V. A. Smolii et al.; Institute of History of Ukraine NAS of Ukraine. Kyiv: Naukova Dumka. Vol. 1 : A-B. 688 p.

Highest order. Department two. Part one Official. Podolia Province News. № 7. 1858. P. 1.

The of Journal of Department of State Economics on the arrangement of retired and before-term retired soldiers, with supplement of M. S. Voronontsov's remarks on the $2^{\text {nd }}$ Infantry Corps under his command. Russian State Archives of Ancient Acts (RSAAA). Section 1261 (Pr. Vorontsovs). Box 1, Folder 2247, ff. 2-27.

On the charge of robbery of Frants Krayevskyi's house by a before-term retired ordinary Klym Berezov and peasants Feodosiy Polishchuk, Parfiriy Shevchyshyn. State Archives of Khmelnytskyi region. Section 642 (Military Court Commission under Kamyanets-Podilsky Military Chief's Office). Box 1, Folder 6, ff. 9-10; 93-95.

Zajonchkovskyi P. A. (1952). Military reforms of 1860-1870 in Russia. Moscpe: MSU Publishing House. 375 p.

Copy of the Ministry of Inner Affairs Circular about the settlement of the retired army lower rank servicemen and a draft of M. F. Golitsyn's note to the Moscow Governor. RSAAA. Section 1263 (the Earls Golitsyns), Box. 6, Folder 6, ff. 2-7. 
The manifesto of Tsar Alexander II, the decrees of the Senate on the recruitment of private doctors to military service. State Archives of Khmelnytskyi region. Section 69 (Podillia Province Medical Administration), Box 1, Folder 442, ff. 6-7.

Miliutin D. A. (1919). Memoirs. Vol 1 (1816-1843). Moscow: Military Academy Publishing House, $469 \mathrm{p}$.

Molchanov V. B. (2012-2013). Impact of D. O. Miliutin's military reforms on life support for the Russian military in the Ukrainian provinces in the second half of the $19^{\text {th }}$ cent. Problems of History of Ukraine of the $19^{\text {th }}$-early $20^{\text {th }}$ cent. Issue 20. P. 171-201, Issue 22. P. 78-120.

Unknown (1895). Memoirs for many years. 1844-1884. Russian antiquity. Year XXVI. Volume LXXXIII. Issue 2. Saint-Petersburg. P. 121-134.

Concerning the lower rank servicemen who are considered to be in hospitals: in the war of 1853-1856. The highest orders. Part official. Podolie Eparchy News. January 15,1864 . № 2. P. 1.

Memorable Book of Podolia Province for 1859. Issued by Podolia Provincial News Publishing House (1859). Kamenets-Podolsk. 177 p.

CSLRE 1. Law № 30379. On discontinuance of secondary military enlisting of retired lower rank servicemen with special privileges; Law № 30409. On the order of the officers's leaves on family reasons, in 1856; Law № 30410. On the order of allowance to leave for home of lower rank servicemen legitimate for retiring; Law № 30454. On the order of the officer's leave with maintenance; Law № 31161. On the order of indefinite-termed leave of staff and chief-officers. In: A Complete Set of Laws of the Russian Empire (from now on - CSLRE-II). Vol. XXXI. Sect. 1. SaintPetersburg: Publishing House II of H.I.M. office, 1857.

CSLRE 2. Law № 30493. The highest approved Rules for lower rank servicemen leave for vacation and retirement; Law № 30906. On the form of the card for the lower rank servicemen who volunteered to join the military during the last war, out of state peasants who are due for retiring for indefinite-termed leave; To Law № 30906. Form of the card for lower-rank servicemen who joined the military during the war time, willingly, out of state peasants. In: CSLRE-II. Vol. XXXI. Dept. 1; Sect. 2. Saint-Petersburg: Publishing House II of H.I.M. office, 1857.

CSLRE 3. Law № 31377. On the privileges of generals in reserve troops and indefinite-termed officers occupying the posts concerning the nobility election. In: CSLRE-II. Vol. XXXII. Sect. 1. Saint-Petersburg: Publishing House II of H.I.M. office, 1858. P. 36.

CSLRE 4. Law № 31679. On the order of indefinite-termed leaves of staff and chief-officers. In: CSLRE-II. Vol. XXXII. Sect. 1. Saint-Petersburg: Publishing House II of H.I.M. office, 1858. P. 268-269.

CSLRE 5. Law № 31762. On the color of the cards for indefinite-termed lowerrank servicemen; Law № 32461. On the form of shoulder straps and stripes or nuts for the lower rank servicemen in the indefinite-termed or temporary leave; Drawings and pictures to Law № 32461. Picture of shoulder straps with stripes of black cloth for lower rank servicemen in the leave. In: CSLRE-II. Vol. XXXII. Sect. 2. SaintPetersburg: Publishing House II of H.I.M. office, 1858.

CSLRE 6. Law № 32517. On sending the lower-rank servicemen to short-termed leaves. In: CSLRE-II. Vol. XXXII. Sect. 1. Saint-Petersburg: Publishing House II of H.I.M. office, 1858. P. 982-983. 
CSLRE 7. Law № 32740. The highest approved Rules for the leave of the generals, staff and chief-officers being on service in the troops and military Administration, for participating in the nobility assemblies, and allowance for them in case of being elected members of the Province Committees, to stay there for the whole duration of the committees. In: CSLRE-II. Vol. XXXIII. Sect. 1. Saint-Petersburg: Publishing House II of H.I.M. office, 1860. P. 91-92.

CSLRE 8. Law № 33294. On the terms for the indefinite-termed leave, in 1858, of the lower-rank servicemen. In: CSLRE-II. Vol. XXXIII. Sect. 1. Saint-Petersburg: Publishing House II of H.I.M. office, 1860. P. 753-754.

CSLRE 9. Law № 34401. On appointment of people quite appropriate for the police service from the military to the police. In: CSLRE-III. Vol. XXXIII. Sect. 1. Saint-Petersburg: Publishing House II of H.I.M. office, 1861. P. 376.

Volkovynskyi V. M., Rejent O. P. (2006) Ukraine in the Crimean War of 1853-1856 (to the $150^{\text {th }}$ anniversary of the Eastern War). Kyiv: Institute of History of Ukraine NAS of Ukraine. $211 \mathrm{p}$.

Rejent O. P. (2015) Why did the Crimean War of 1853-1856 become an event of international social life? In: History of the Crimea in questions and answers. Kyiv: NAS of Ukraine. Institute of History of Ukraine. 527 p.

Collection of statistic data about Kyiv Provence for 1859 (with address-calendar of the people in service of the province for the year of 1861) (1861). Kiev: Province Administration Publishing House. 281 p.

Skrypnyk A. Ju. (2015) Order and specifics of firing of the officers of the Russian Empire military forces in 30-50s of the $19^{\text {th }}$ cent. Newsletter of Kamianets-Podilskyi National Ivan Ohiienko University. Historical Sciences. Issue 8. P. 192-200.

Skrypnyk A. Ju. (2015) Politics of staff militarization of the local administrative apparatus of Right Bank Ukraine provinces in 20-60s of the $19^{\text {th }}$ cent. Journal of Ukrainian history. Issue 32. P. 38-45.

The case for prosecution of indefinite-termed cannoneer Jukhym Shandriuk accused of stealing cantor's Strelbitskyi's food stuffs. State Archives of Vinnytsia Region. Section D-222 (Lityn county court), Box 1, Folder 620, ff. 1-2, 5-6 rev., 26-27.

The case of appropriation by a townsman Tkachenko of a hereditary house owned by a retired bombardier Slipchenko. State Archives of Cherkasy Region. Section 384 (Zvenyhorod town magistrate). Box 1, Folder 290, ff. 1-1 rev., 8-9, 28-32, 58.

Circulars of Kyiv military, Podilskyi and Volynskyi governor-generals for 1858-1860. State Archives of Rivne Region. Section 567 (Dubno town magistrate). Box 1, Folder 3, f. 3.

Circulars of Podilskyi provincial administration and correspondence with it concerning the release of pastures for horses from military units. State Archives of Vinnytsia Region. Section D-200 (Vinnytsia count nobility leader). Box 1, Folder 372, f. 41.

Circular letters of Volyn province administration about keeping the documents, functioning of Polish revolutionary committee and supplying information about officers of Polish nationality and the counties residents. Reports of bailiffs about lists of personnel. State Archive of Rivne Region. Section 379 (Rivne county clerk). Box 2, Folder 2, f. 5-9. 


\section{SKRYPNYK A.}

\section{OPTIMIZATION OF RUSSIAN ARMED FORCES IN LATE $1850^{\mathrm{TH}}$ EARLY 1860}

The paper considers transformation processes going on in the Russian Imperial Army from the middle of $1850 \mathrm{~s}$ after the diplomatic and military defeat in the Eastern (Crimean) War against the coalition of European states. The author outlines the measures undertaken by the Government and Military Ministry in order to cut down the number of personnel in military units, formation of necessary legislative background to regulate the status of a military man on vacation outside the military unit. Special attention focuses on the attempts of the Russian Army to transform the principles of regular units formation, in particular improvement of officer personnel. The paper shows the way former soldiers and officers used to be employed in civil life and how provincial and local authorities facilitated it offering them jobs in the structures of aristocratic and rural management. Imperial military forces reformation resulted in the social structure of towns, cities and villages, the increased number of former military men influenced their relations with local population.

Maintenance of a big army is proved to be a sufficient expenditure from the state budget so striving to make the correspondence between quantity and costs has been of top importance. The Russian Imperial Army of the early $19^{\text {th }}$ century during the reign on Nikolai the First where the number of the military and the term of their service were the priority of the army construction was an excellent example, and serfdom was a social basis. The Eastern (Crimean) War made clear that such army was not effective and the number of soldiers was not a crucial advantage in front of contemporary armament and organization of the Europeans. As a result, the number of the allies defeated the Russians. Thus, the historic practice of quick army reformation (reduction) may serve an example for the Ukrainian military forces when the external threats disappear and there arises a necessity of transformation according to up-to-date optimal models of European armies.

Military conflict between the Russian Empire and European countries in the middle of the $19^{\text {th }}$ century exposed the drawbacks in the Russian military forces. The vacation system and formation of emergency and reserve troops during 20-50ies were rather effective maintaining the army in the proper combat readiness and preserving its necessary number. Hence, the Crimean War disclosed several key reasons of false military strategy based on serfdom. First, weak reserves and burdensome vast number of local troops not meant for war. Second, the serfdom prevented the reduction of service terms and training enough number of the military for reserves formation. Third, during active military actions it was impossible to reduce the number of local troops by recruiting them into the army regiments as far as they were used to powerfully support the serfdom in the rears. Therefore the army reformation reflected thorough social and economic shifts in the Russian state mechanism. Anachronistic serfdom evidently backed off all spheres of life. The crucial changes in the military forces did not strengthen the defensive potential of the country but served to prepare for new conquering wars as an instrument of Russian imperial politics in the $19^{\text {th }}$ century.

Keywords: Russian Empire, Russian military forces, reformation, legislative base. 